\title{
SIRT2 Contributes to the Resistance of Melanoma Cells to the Multikinase Inhibitor Dasatinib
}

\author{
Iwona Karwaciak ${ }^{1}$, Anna Sałkowska ${ }^{2}$, Kaja Karaś ${ }^{2}$, Marta Sobalska-Kwapis 3,4 ${ }^{\mathbb{D} \text {, }}$ \\ Aurelia Walczak-Drzewiecka ${ }^{5}$, Łukasz Pułaski ${ }^{1}$ D, Dominik Strapagiel ${ }^{3,4}{ }^{\mathbb{D}}$, Jarosław Dastych 5 \\ and Marcin Ratajewski ${ }^{2, * \mathbb{D}}$ \\ 1 Laboratory of Transcriptional Regulation, Institute of Medical Biology, Polish Academy of Sciences, \\ 93-232 Lodz, Poland; isachrajda@cbm.pan.pl (I.K.); lpulaski@uni.lodz.pl (Ł.P.) \\ 2 Laboratory of Epigenetics, Institute of Medical Biology, Polish Academy of Sciences, 93-232 Lodz, Poland; \\ annaswiderek1@wp.pl (A.S.); kaja.karas@gmail.com (K.K.) \\ 3 Biobank Lab, Department of Molecular Biophysics, Faculty of Biology and Environmental Protection, \\ University of Lodz, 90-237 Lodz, Poland; marta.sobalska@biol.uni.lodz.pl (M.S.-K.); \\ dominik.strapagiel@biol.uni.lodz.pl (D.S.) \\ 4 BBMRI.pl Consortium, 54-066 Wroclaw, Poland \\ 5 Laboratory of Cellular Immunology, Institute of Medical Biology, Polish Academy of Sciences, \\ 93-232 Lodz, Poland; adrzewiecka@cbm.pan.pl (A.W.-D.); jdastych@cbm.pan.pl (J.D.) \\ * Correspondence: mratajewski@cbm.pan.pl; Tel.: +48-42-209-3389
}

Received: 5 April 2019; Accepted: 12 May 2019; Published: 14 May 2019

\begin{abstract}
Malignant melanoma is the most aggressive skin cancer and can only be cured if detected early. Unfortunately, later stages of the disease do not guarantee success due to the rapid rate of melanoma cell metastasis and their high resistance to applied therapies. The search for new molecular targets and targeted therapy may represent the future in the development of effective methods for combating this cancer. SIRT2 is a promising target; thus, we downregulated SIRT2 expression in melanoma cells in vertical growth and metastatic phases and demonstrated that sirtuin acts as regulator of the basic functions of melanoma cells. A detailed transcriptomic analysis showed that SIRT2 regulates the expression of multiple genes encoding the tyrosine kinase pathways that are molecular targets of dasatinib. Indeed, cells with low SIRT2 expression were more susceptible to dasatinib, as demonstrated by multiple techniques, e.g., neutral red uptake, 3/7 caspase activity, colony formation assay, and in vitro scratch assay. Furthermore, these cells showed an altered phosphorylation profile for proteins playing roles in the response to dasatinib. Thus, our research indicates new, previously unknown SIRT2 functions in the regulation of gene expression, which is of key clinical significance.
\end{abstract}

Keywords: melanoma; SIRT2; sirtuins; tyrosine kinase; resistance

\section{Introduction}

Malignant melanoma is the most aggressive skin cancer, and its incidence is increasing each year [1]. Standard chemotherapy with dacarbazine and immunotherapy with recombinant IL-2 or INF $\alpha$ provide low response rates, and have no effect on the overall survival of patients [2-6]. Combination therapy with several compounds used concurrently, e.g., cisplatin, vinblastine, and dacarbazine (CVD regiment) or cisplatin, dacarbazine, carmustine, and tamoxifen (DBCT regiment, or Darmouth regimen), shows a greater response rate percentage [7-9], but does not significantly influence overall survival [3]. Failures in the treatment of advanced melanomas are caused by the intrinsic resistance of the cells to known chemotherapeutic agents, which may be related to melanocyte physiology, particularly the production of melanin. This metabolic process generates many highly cytotoxic compounds that create 
the endogenous melanogenic cytotoxicity (EMC) to which melanocytes are well adapted $[10,11]$. It is possible that the factor(s) that allows a normal cell to perform its function also supplies a cancer cell with a weapon that we are not yet able to defeat. The exact processes by which resistance is acquired by melanoma cells are, to a great extent, unknown, and our knowledge in this area is greatly limited. There is evidence that the regulation of apoptosis-related processes by overexpression of some proteins, such as ABC transporters, may have significance [12-16]. Other potential mechanisms of resistance include the altered expression of transcription factors (e.g., MITF) [17] and the interaction of melanoma cells with fibroblasts and macrophages in the tumor microenvironment [18-21].

As mentioned earlier, standard therapy for melanoma patients provides poor results. Nevertheless, understanding the molecular mechanisms by which melanoma cells acquire the ability to undergo uncontrolled proliferation has facilitated the discovery of new therapeutic targets and the development of targeted therapy. A high percentage $(66 \%)$ of malignant melanomas carry the V600E BRAF gene mutation [22]. This mutation results in constitutive expression of the active protein activating the MAPK pathway via MEK1/2 and ERK1/2 [23] and dysregulation of the control of proliferation, differentiation, adhesion and migration [21,24]. This discovery led to the development of mutant-specific inhibitors of BRAF, vemurafenib (PLX4032) [25,26] and dabrafenib [27], which provided better clinical responses, including improved overall survival of melanoma patients compared with standard chemotherapy regimens $[28,29]$. Although the use of new inhibitors has improved chemotherapy for melanomas, the clinical response to these novel drugs is not permanent, and typically lasts for 6-8 months due to the acquisition of drug resistance by mutational or altered genetic expression events that reactivate the MAPK pathway [30-34].

Among potential molecular therapeutic targets in melanoma that have recently been gathering attention are sirtuins [35,36], which are $\mathrm{NAD}(+)$-dependent, multifunctional lysine deacylases characterized by a conserved catalytic domain, the sirtuin core domain, and N- and C-terminal domains that differ in different proteins [37-40]. Different sirtuins exhibit different intracellular localizations. SIRT3, 4 and 5 are localized in mitochondria [41], while SIRT1, 2, 6 and 7 are considered nuclear proteins [42,43]. However, SIRT1 and 2 can also localize in the cytoplasm [44,45]. Most studies of sirtuin functions in melanoma have concentrated on SIRT1 [46-48]; however, our group [49] and others [50] have also demonstrated the possible involvement of SIRT2 in the multidrug resistance of melanomas. Using in vitro melanoma cell line-based screening, we previously identified an inhibitor of SIRT2, AC-93253, as a compound that downregulates the expression of genes involved in melanoma progression and chemoresistance acquisition [49]. This compound was subsequently also identified as an SRC inhibitor [51]. These findings prompted us to perform a more detailed analysis of the role of SIRT2 in melanoma cells. We created melanoma cell lines with downregulated SIRT2 expression in the early and metastatic phases and examined their gene expression and resistance to dasatinib treatment. We found that downregulation of SIRT2 drastically altered the gene expression profiles of melanoma cells and sensitized them to dasatinib, suggesting a potential role for SIRT2 in the melanoma therapy failures of this drug.

\section{Results}

\subsection{Identification of SIRT2-Dependent Genetic Information in Melanoma Cells}

To characterize the role of SIRT2 in melanoma cells, we downregulated the expression of this gene in two human melanoma cell lines: WM853 and MDA-MB-435S. Because earlier work has suggested that the role of SIRT2 may vary depending on the stage of disease [52], we chose two cell lines representing different stages of disease development (primary/vertical growth P/VG-WM853 and metastasis-MDA-MB-435S). When SIRT2 expression was analyzed at the protein level, the protein was below the detection level in clones transfected with SIRT2 shRNA. However, SIRT2 protein levels were the same in maternal lines in cells transfected with the control shRNA (Figure 1a). Initially, inhibition of SIRT2 expression significantly affected the phenotype in both cell lines (Figure S1a). This 
finding encouraged us to analyze cellular clones for gene expression profiles. To achieve this goal, RNA-seq analysis of control cells and cells with downregulated SIRT2 expression was performed. The resultant data were processed with three bioinformatics software packages: DESeq v1.32 [53], DESeq2 v1.20.0 [54] and edgeR v3.1 [55]. To identify the most significant hits, we considered only genes that were identified in all three bioinformatics analyses (to show how each tool overlaps with other tools, Venn diagrams were used, Figure S2). In WM853 and MDA-MB-435S cells, we found 3550 and 624 differentially expressed transcripts, respectively. Gene ontology analysis revealed that GO terms related to adhesion, migration, differentiation, and proliferation were overrepresented (in both melanoma cell lines) among the differentially expressed genes (Table S1 and Dataset S3). Comparisons of changes in gene expression resulting from SIRT2 depletion in the two examined cell lines showed that the expression of certain genes was altered in the same direction in the considered cell lines (e.g., ITGA1, EGFR, EPHA2, and CDKN2D were downregulated, and FGFR1 was upregulated in both cell lines), while the expression of other genes showed an opposite direction of change (e.g., SDC2 and NCAM1, upregulated in WM863 and downregulated in MDA-MB-435S; AXL, downregulated in WM863 and upregulated in MDA-MB-435S). They also included genes with altered expression in only one of the SIRT2-depleted cell lines (Tables 1 and 2). A list of the genes that were differentially expressed included several genes coding adhesion receptors associated with cell migration, proliferation, and metastasis (integrins, cadherins, selectins, syndecans) [56-59] and cell cycle regulators [60-62] (Tables 1 and 2). A particularly interesting category of differentially expressed genes comprised those encoding receptor tyrosine kinases as well as other signaling proteins involved in the MAP/ERK pathway, indicating that this particular signaling pathway might be directly or indirectly controlled by SIRT2 (Tables 1 and 2). To assess whether the genes identified in the RNA-seq analysis were subject to expression changes in other melanoma cells when SIRT2 was inhibited, we treated A375 cells (stage: metastasis) with the SIRT2 inhibitor thiomyristoyl [63]. In contrast to other SIRT2 inhibitors, this compound inhibits deacetylation and demyristoylation functions of SIRT2 [64]. The pharmacological inhibition of SIRT2 in A375 resulted in significant inhibition of EGFR, EPHA2, ITGA1, SDC2, DDR1 and EPHB1 that was similar to the SS15 clone in MDA-MB-435S cells (Table S2).
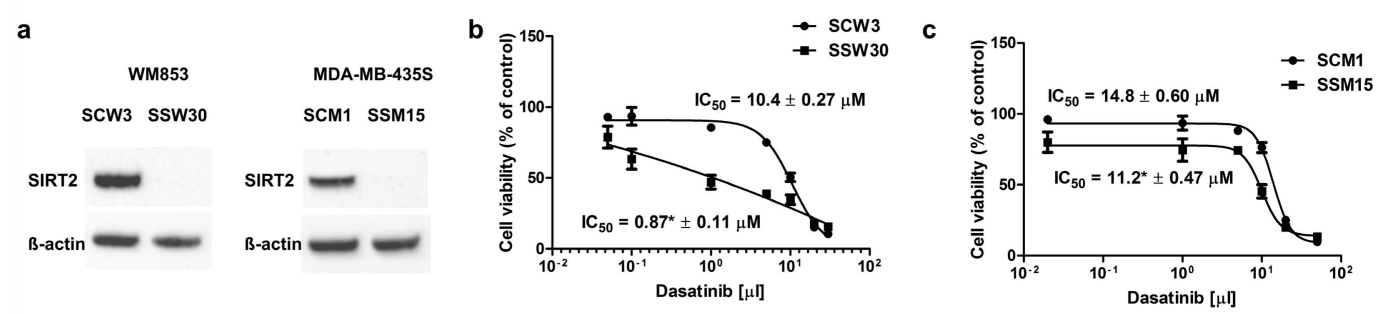

Figure 1. Cellular WM853 and MDA-MB-435S clone characteristics. (a) SIRT2 expression in SCW3 and SSW30 clones of WM853 cells and SCM1 and SSM15 clones of MDA-MB-435S as evidenced by Western blotting. (b) The cytotoxic effects of dasatinib treatment $(48 \mathrm{~h})$ on melanoma SCW3 and SSW30 clones of the WM853 cell line, as evidenced using the neutral red assay, mean $\pm \mathrm{SD},(n=3$, independent experiments) (c) The cytotoxic effects of dasatinib treatment ( $48 \mathrm{~h}$ ) on melanoma SCM1 and SSM15 clones of the MDA-MB-435S cell line, as evidenced using the neutral red assay, mean $\pm \mathrm{SD},(n=3$, independent experiments). 
Table 1. Selected category of genes (based on a literature search) with changes in expression in WM853 cells with SIRT2 downregulation as determined using RNA-seq.

\begin{tabular}{|c|c|c|c|}
\hline Gene Symbol & Protein & Effect & Average Fold Change \\
\hline \multicolumn{4}{|c|}{ Integrins } \\
\hline ITGA1 & integrin subunit alpha 1 & $\downarrow$ & 0.462 \\
\hline ITGA3 & integrin subunit alpha 3 & $\uparrow$ & 2.173 \\
\hline ITGA4 & integrin subunit alpha 4 & $\downarrow$ & 0.556 \\
\hline ITGA5 & integrin subunit alpha 5 & $\uparrow$ & 1.588 \\
\hline ITGA6 & integrin subunit alpha 6 & $\uparrow$ & 2.221 \\
\hline ITGA9 & integrin subunit alpha 9 & $\uparrow$ & 2.498 \\
\hline ITGA11 & integrin subunit alpha 11 & $\downarrow$ & 0.551 \\
\hline ITGAE & integrin subunit alpha E & $\downarrow$ & 0.540 \\
\hline ITGAL & integrin subunit alpha L & $\downarrow$ & 0.540 \\
\hline \multicolumn{4}{|c|}{ Cadherins } \\
\hline $\mathrm{CDH} 2$ & cadherin 2 & $\uparrow$ & 1.770 \\
\hline CDH19 & cadherin 19 & $\uparrow$ & 4.203 \\
\hline \multicolumn{4}{|c|}{ Selectins } \\
\hline SELL & Selectin L & $\uparrow$ & 8.589 \\
\hline \multicolumn{4}{|c|}{ Syndecans } \\
\hline SDC1 & syndecan 1 & $\downarrow$ & 0.300 \\
\hline$S D C 2$ & syndecan 2 & $\uparrow$ & 4.304 \\
\hline \multicolumn{4}{|c|}{ Immunoglobulin-like Cell Adhesion Molecules } \\
\hline NCAM1 & neural cell adhesion molecule & $\uparrow$ & 21.328 \\
\hline \multicolumn{4}{|c|}{ Receptor tyrosine kinases } \\
\hline EGFR & epidermal growth factor receptor & $\downarrow$ & 0.456 \\
\hline$I G F 1 R$ & insulin like growth factor 1 receptor & $\uparrow$ & 1.653 \\
\hline IGFLR1 & IGF like family receptor 1 & $\downarrow$ & 0.647 \\
\hline FGFR1 & fibroblast growth factor receptor 1 & $\uparrow$ & 4.052 \\
\hline NGFR & nerve growth factor receptor & $\downarrow$ & 0.579 \\
\hline EPHA2 & $\mathrm{EPH}$ receptor $\mathrm{A} 2$ & $\downarrow$ & 0.477 \\
\hline ЕРНАЗ & $\mathrm{EPH}$ receptor A3 & $\uparrow$ & 1.646 \\
\hline EPHA5 & $\mathrm{EPH}$ receptor A3 & $\downarrow$ & 0.421 \\
\hline ЕРНB3 & EPH receptor B3 & $\uparrow$ & 2.767 \\
\hline$A X L$ & AXL receptor tyrosine kinase & $\downarrow$ & 0.592 \\
\hline ROR1 & receptor tyrosine kinase like orphan receptor 1 & $\uparrow$ & 2.547 \\
\hline \multicolumn{4}{|c|}{ MAP/ERK pathway } \\
\hline GRB14 & growth factor receptor bound protein 14 & $\uparrow$ & 3.678 \\
\hline RASAL1 & RAS protein activator like 1 & $\uparrow$ & 7.833 \\
\hline RASD2 & RASD family member 2 & $\uparrow$ & 3.716 \\
\hline RASEF & RAS and EF-hand domain containing & $\uparrow$ & 2.321 \\
\hline RASGEF1C & RasGEF domain family member $1 C^{\circ}$ & $\downarrow$ & 0.195 \\
\hline RASGRP1 & RAS guanyl releasing protein 1 & $\uparrow$ & 6.635 \\
\hline RASGRP3 & RAS guanyl releasing protein 3 & $\downarrow$ & 0.417 \\
\hline RASSF2 & Ras association domain family member 2 & $\uparrow$ & 2.186 \\
\hline RASSF4 & Ras association domain family member 4 & $\downarrow$ & 0.594 \\
\hline RASSF5 & Ras association domain family member 5 & $\uparrow$ & 2.972 \\
\hline$M A P 2 K 3$ & mitogen-activated protein kinase kinase 3 & $\downarrow$ & 0.593 \\
\hline$M A P 2 K 6$ & mitogen-activated protein kinase kinase 6 & $\uparrow$ & 2.309 \\
\hline МАРЗК4 & mitogen-activated protein kinase kinase kinase 4 & $\downarrow$ & 0.598 \\
\hline MAP3K14 & mitogen-activated protein kinase kinase kinase 14 & $\downarrow$ & 0.585 \\
\hline MAP3К21 & mitogen-activated protein kinase kinase kinase 21 & $\uparrow$ & 3.521 \\
\hline \multicolumn{4}{|c|}{ Other protein kinases } \\
\hline BTK & tyrosine-protein kinase BTK & $\downarrow$ & 0.342 \\
\hline GAK & cyclin G-assiciated kinase & $\downarrow$ & 0.583 \\
\hline$L Y N$ & tyrosine protein kinase LYN & $\downarrow$ & 0.275 \\
\hline \multicolumn{4}{|c|}{ Cell cycle regulators } \\
\hline CDK5R1 & cyclin dependent kinase 5 regulatory subunit 1 & $\downarrow$ & 0.653 \\
\hline CDK6 & Cyclin-dependent kinase 6 & $\uparrow$ & 1.660 \\
\hline$C D K L 2$ & cyclin dependent kinase like 2 & $\uparrow$ & 2.001 \\
\hline CDKN1A & Cyclin-dependent kinase inhibitor 1A (P21WAF) & $\downarrow$ & 0.615 \\
\hline$C D K N 2 B$ & cyclin dependent kinase inhibitor 2B & $\uparrow$ & 4.107 \\
\hline CDKN2C & cyclin dependent kinase inhibitor $2 \mathrm{C}$ & $\downarrow$ & 0.546 \\
\hline$C D K N 2 D$ & cyclin dependent kinase inhibitor 2D & $\downarrow$ & 0.587 \\
\hline
\end{tabular}

Average fold change: the difference in gene expression levels between WM853 SCW3 and WM853 SSW30 clones was counted as the mean fold change in the deseq, deseq2 and edgeR analyses. 
Table 2. Selected category of genes (based on a literature search) with changes in expression in MDA-MB-435S cells with SIRT2 downregulation as determined using RNA-seq.

\begin{tabular}{|c|c|c|c|}
\hline Gene Symbol & Protein & Effect & Average Fold Change \\
\hline \multicolumn{4}{|c|}{ Integrins } \\
\hline ITGA1 & integrin subunit alpha 1 & $\downarrow$ & 0.051 \\
\hline ITGBL1 & integrin subunit beta like 1 & $\downarrow$ & 0.227 \\
\hline \multicolumn{4}{|c|}{ Cadherins } \\
\hline CDH12 & cadherin 12 & $\uparrow$ & 8.313 \\
\hline \multicolumn{4}{|c|}{ Syndecans } \\
\hline SDC2 & syndecan 2 & $\downarrow$ & 0.452 \\
\hline \multicolumn{4}{|c|}{ Immunoglobulin-like Cell Adhesion Molecules } \\
\hline NCAM1 & neural cell adhesion molecule & $\downarrow$ & 0.572 \\
\hline ICAM5 & intercellular adhesion molecule 5 & $\downarrow$ & 0.449 \\
\hline \multicolumn{4}{|c|}{ Receptor tyrosine kinases } \\
\hline EGFR & epidermal growth factor receptor & $\downarrow$ & 0.195 \\
\hline FGFR1 & fibroblast growth factor receptor 1 & $\uparrow$ & 2.005 \\
\hline EPHA2 & EPH receptor A2 & $\downarrow$ & 0.423 \\
\hline EPHB1 & EPH receptor $\mathrm{B} 1$ & $\downarrow$ & 0.360 \\
\hline$A X L$ & AXL receptor tyrosine kinase & $\uparrow$ & 2.086 \\
\hline DDR1 & Discoidin domain receptor family, member 1 & $\downarrow$ & 0.576 \\
\hline \multicolumn{4}{|c|}{ MAP/ERK pathway } \\
\hline GRB14 & growth factor receptor bound protein 14 & $\downarrow$ & 0.234 \\
\hline RASL10B & RAS like family 10 member B & $\uparrow$ & 2.220 \\
\hline МАРЗК9 & mitogen-activated protein kinase kinase kinase 9 & $\downarrow$ & 0.638 \\
\hline MAPK8IP1 & mitogen-activated protein kinase 8 interacting protein 1 & $\downarrow$ & 0.342 \\
\hline MAPK8IP2 & mitogen-activated protein kinase 8 interacting protein 2 & $\downarrow$ & 0.587 \\
\hline \multicolumn{4}{|c|}{ Cell cycle regulators } \\
\hline CDK14 & Cyclin-dependent kinase 14 & $\downarrow$ & 0.207 \\
\hline CDK18 & Cyclin-dependent kinase 18 & $\uparrow$ & 1.536 \\
\hline CDK20 & Cyclin-dependent kinase 20 & $\downarrow$ & 0.073 \\
\hline$C D K N 2 D$ & cyclin dependent kinase inhibitor 2D & $\downarrow$ & 0.643 \\
\hline
\end{tabular}

\subsection{SIRT2-Inhibition Sensitizes Melanoma Cells to Dasatinib}

Analyses of the transcriptomes of the created SIRT2-deficient cell lines revealed the altered expression of numerous genes identified as targets of dasatinib (e.g., EGFR, EPHA2, EPHB1, BTK, MAP3K4, MAP3K14, DDR1, GAK, and LYN) [65,66] (Tables 1 and 2), which prompted us to examine whether SIRT2 downregulation could sensitize melanoma cells to dasatinib. Cells with low expression of SIRT2 were more sensitive to dasatinib treatment compared with those with normal expression of the gene (Figure $1 b, c$ ), and this effect was accompanied with higher susceptibility to early membrane damage and apoptosis (Figure S3). However, it should be noted that the effects of dasatinib were much stronger in the $\mathrm{P} / \mathrm{VG}$ cell line than in the cell line representing the metastasis stage.

To confirm the differences in the reproductive viability of cells with low SIRT2 expression following dasatinib treatment, we performed colony formation assays. Inhibition of SIRT2 expression had a much greater impact on the ability to form colonies in the P/VG line (WM853), and treatment with dasatinib further reduced the cell potential for colony formation (Figure 2a). In the metastatic melanoma line, inhibition of SIRT2 expression had a slightly reduced effect on colony formation in the control-treated cells, and treatment with dasatinib had much smaller effect on colony formation in the SIRT2-deficient cell line (Figure $2 b$ ) than in the P/VG line. We next investigated the effects of the combination of SIRT2 knockout and dasatinib treatment on the migratory function of melanoma cells using the scratch assay. Our results showed that lack of SIRT2 expression in the P/VG melanoma line significantly inhibited cell motility by 4.5 -fold $(24 \mathrm{~h})$ to 470 -fold $(48 \mathrm{~h})$, and treatment with dasatinib strongly increased the observed inhibitory effects of SIRT2 depletion (Figure 3a and Figure S4a). In metastatic cells (Figure 3b 
and Figure S4b), the lack of SIRT2 expression caused 2.5-fold and 5-fold inhibition of migration, but the effect of dasatinib in SIRT2-deficient cells seems to be reduced compared to that of control cells. One possible explanation is that the lack of SIRT2 decreased the migratory potential of cells to the extent where any additional inhibitory effects are difficult to observe.

a
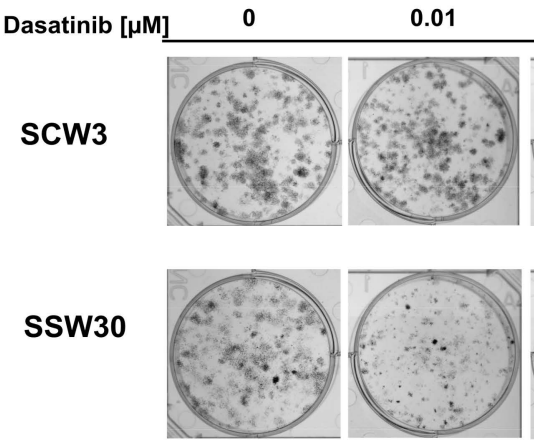

b Dasatinib $[\mu \mathrm{M}]$

SCM1

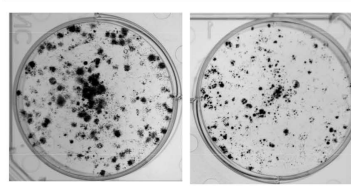

SSM15

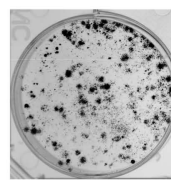

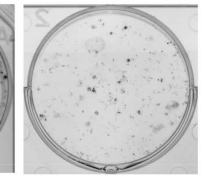

0.01

0.05

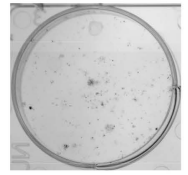

0.05

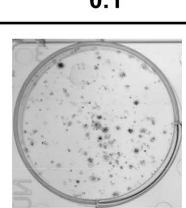

0.1
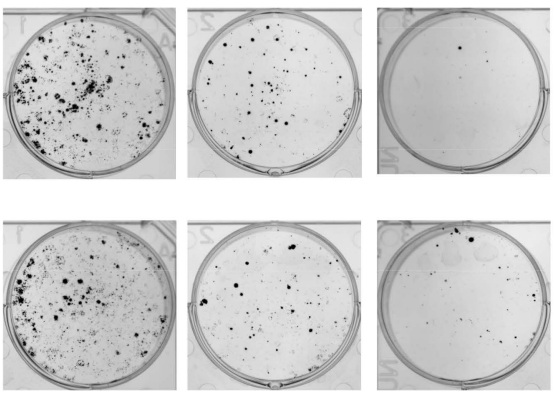

Figure 2. (a) Effect of dasatinib on the capacity of SCW3 and SSW30 cells to produce progeny as determined using the colony formation assay. Images from a single representative experiment (left panel) and a computer-generated area lacking values to illustrate the colony formation assay (right panel), mean $\pm \mathrm{SD},(n=4)$. ${ }^{*}$ Indicates a statistically significant difference at $p<0.05$. (b) Effect of dasatinib on the capacity of SCM1 and SSM15 cells to produce progeny as determined using the colony formation assay. Image from a single representative experiment (left panel) and computer-generated area lacking values to illustrate the colony formation assay (right panel), mean $\pm \mathrm{SD},(n=4)$. * Indicates a statistically significant difference at $p<0.05$. 

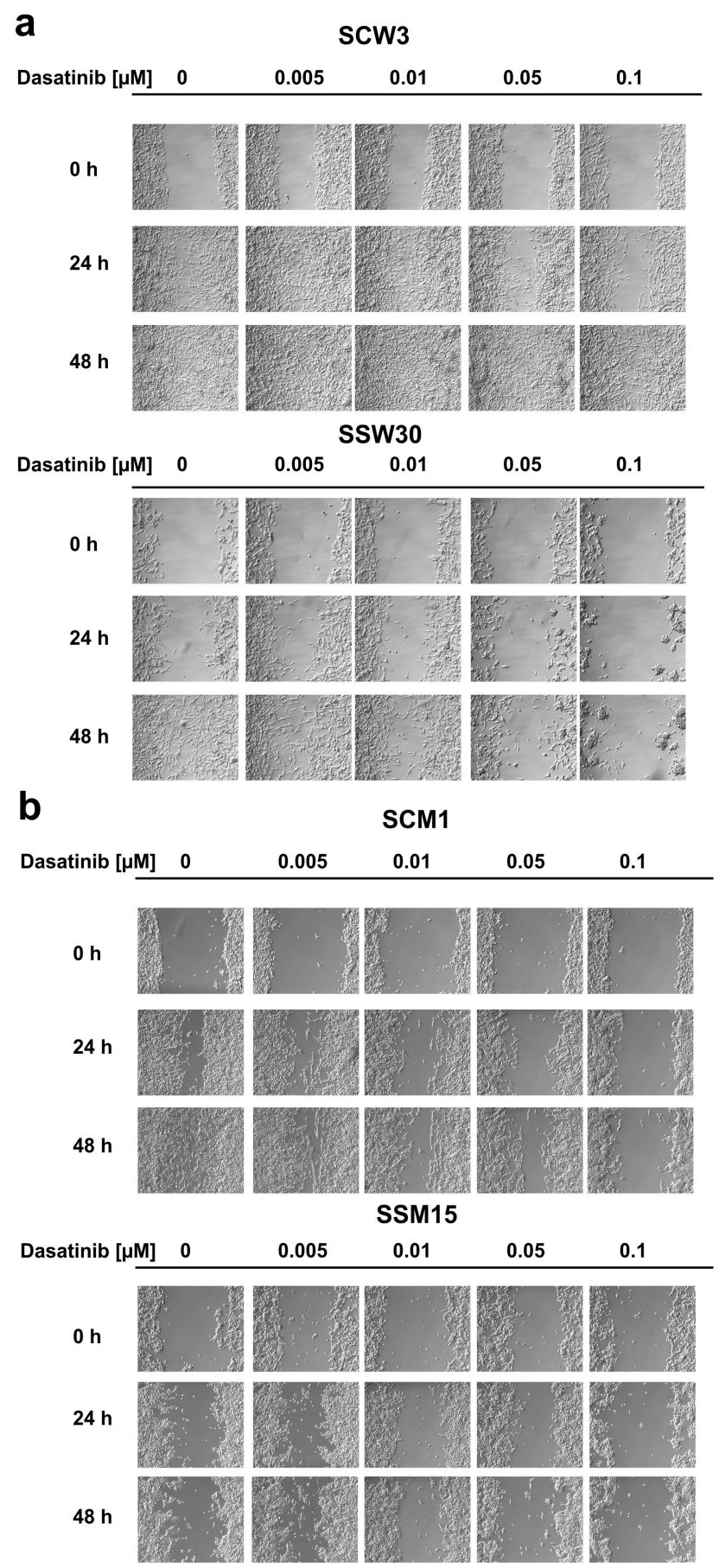

Figure 3. Treatment with dasatinib impairs the migration of melanoma cells based on the scratch assay. (a) Image from a single representative experiment performed using WM853 SCW3 and SSW30 clones. (b) Image from a single representative experiment performed using MDA-MB-435S SCM1 and SSM15 clones. Quantification of above results is shown in the Figure S4. $10 \times 10$ magnification.

\subsection{Effects of SIRT2 Inhibition and Dasatinib on the Cell Cycle Distribution}

To determine the effects of SIRT2 knockdown and dasatinib treatment on the cell cycle, quantification of the percentage of cells in different cell cycle phases was determined after $24 \mathrm{~h}$ of dasatinib treatment. In control WM853 SCW3 cells, $10 \mu \mathrm{M}$ dasatinib treatment caused an increase in the percentage of cells in G1 phase and a decrease in the percentages of cells in S phase (for 5 and $10 \mu \mathrm{M}$ ) (Figure 4a). When analyzing the cell cycle distribution in the WM853 SSW30 clones, we noticed 
that these cells showed a reduced percentage of cells in G1 phase and an increased percentage of cells in S and G2 phases compared to control SCW3 cells. Treatment with dasatinib (especially at high concentrations) led to an increase in the percentage of cells in S phase (10 $\mu \mathrm{M}$ of tested compound) (Figure 4a). For metastatic MDA-MB-435S SCM1 cells, dasatinib decreased the percentage of cells in G1 (0.5-10 $\mu \mathrm{M}$ dasatinib) and G2 phases (5-10 $\mu \mathrm{M}$ dasatinib) and increased those in $S$ phase $(1-10 \mu \mathrm{M}$ dasatinib). MDA-MB435S SSM15 cells showed a reduction in G2 phase cells. Treatment of these cells with dasatinib led to decreases in the percentage of cells in G1 and G2 (0.5-10 $\mu \mathrm{M}$ dasatinib) phases (up to almost complete elimination of cells in G2 phase) and increases in the percentage of cells in $\mathrm{S}$ phase (5-10 $\mu \mathrm{M}$ dasatinib) (Figure $4 \mathrm{~b})$.

scW3

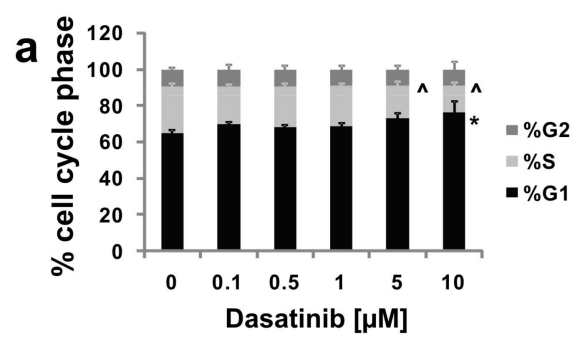

SCM1

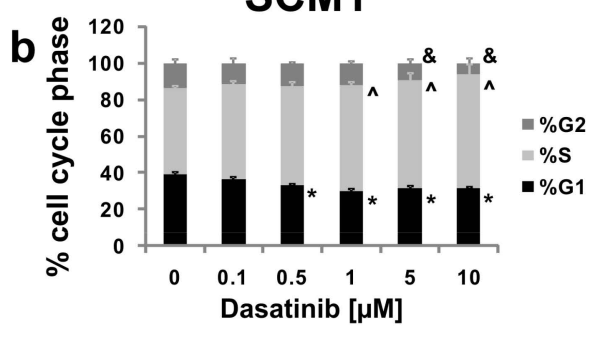

SsW30

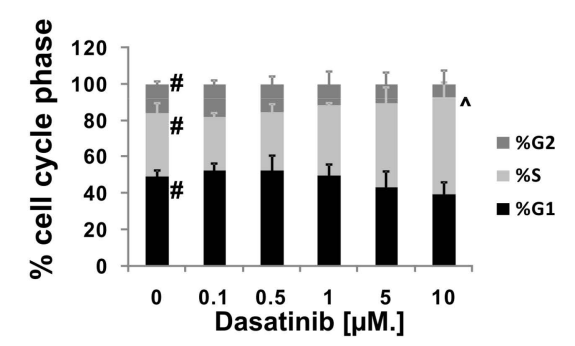

SSM15

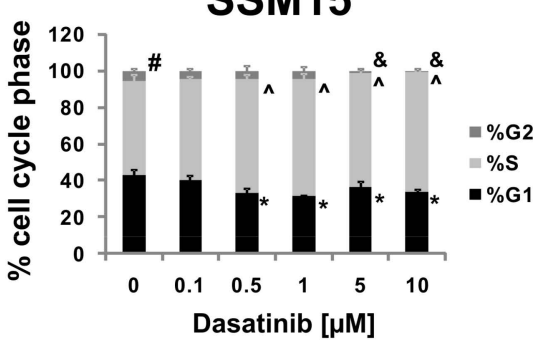

Figure 4. (a) Cell cycle phase distribution in SCW3 and SSW30 clones. (b) Cell cycle phase distribution in SCM1 and SSM15 clones. The data are presented as the mean \pm SD, $(n=3) .{ }^{*}$ Indicates a statistically significant difference at $p<0.05$ in \%G1 phase between dasatinib and control treatment. ^ Indicates a statistically significant difference in $\% \mathrm{~S}$ phase between dasatinib and control treatment at $p<0.05$. \& Indicates a statistically significant difference at $p<0.05$ in \%G2 phase between dasatinib and control treatment. \# Indicates a statistically significant difference at $p<0.05$ for a given phase between control cell line and SIRT2-deficient cells.

\subsection{Modulation of Signaling Pathways by SIRT2 and Dasatinib}

Given the significant role of tyrosine kinase receptors [67,68], downstream signaling of the SRC-ERK [23] pathway in the development of melanomas and their resistance to anticancer drugs and the RNA-seq sequencing results supporting the participation of SIRT2 in the regulation of these pathways, we confirmed that EGFR and EPHA2 receptors were downregulated in cells with low SIRT2 expression (Figures 5a,b, 6a,b and Figure S1b). Although we did not observe the intrinsic phosphorylation of EGFR in any cell line, the differences in the response of the melanoma cells with SIRT2-downregulation to EGF was evident (Figure 5a,b). Similarly, the lack of response of SIRT2-deficient cells to Ephrin-A1 indicates that signal transduction through the EPHA2 receptor in these cells is impaired. Furthermore, we decided to examine the mechanism by which SIRT2 downregulation and dasatinib affects the phosphorylation of downstream elements of the EGFR and EPHA2 pathways. The intrinsic phosphorylation of EPHA2 on Tyr588 decreased in SSW30 clones, and treatment with dasatinib further decreased the phosphorylation. However, a different pattern was observed in analyses of Ser897 phosphorylation. In SSW30 cells, slightly higher phosphorylation was 
detected that increased by dasatinib. In control SCW3 cells, dasatinib led to reduced phosphorylation on Ser897 (Figure 6a). In contrast, in both MDA-MB-435S clones, there were no differences in the intrinsic phosphorylation of EPHA2 on Tyr588, but dasatinib led to phosphorylation inhibition (Figure 6b). SSM15 clones had a lower phosphorylation ratio on Ser897 of EPHA2, and in agreement with our assumptions, the inhibitory effect of dasatinib was stronger in these clones than in the control SCM1 clones (Figure 6b). Next, we analyzed the phosphorylation of the downstream kinases SRC and ERK1/2. We observed that in cells with normal SIRT2 expression, the intrinsic phosphorylation of SRC and ERK1/2 was higher than in cells with SIRT2 knockdown. Treatment with dasatinib increased this effect. We also analyzed the phosphorylation of focal adhesion kinase (FAK), which is crucial for the induction of apoptosis and inhibition of the migratory functions of melanoma cells [69,70]. In both cell lines with low SIRT2 expression, we observed decreased phosphorylation of FAK kinase (Figure 6a,b) that was further decreased by treatment with dasatinib.

\section{SCW3 SSW30}

a

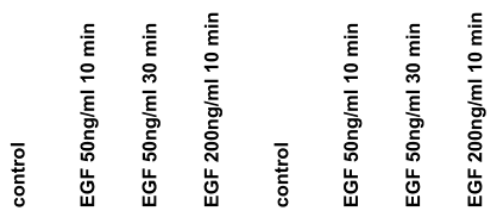

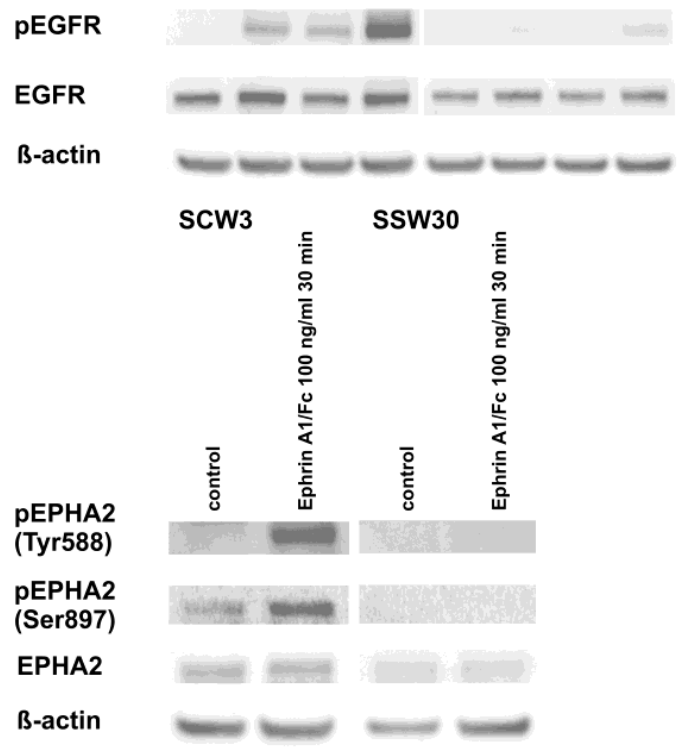

SCM1

b

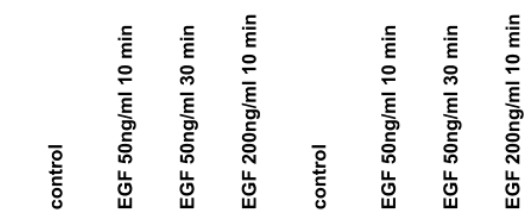

pEGFR

EGFR

B-actin
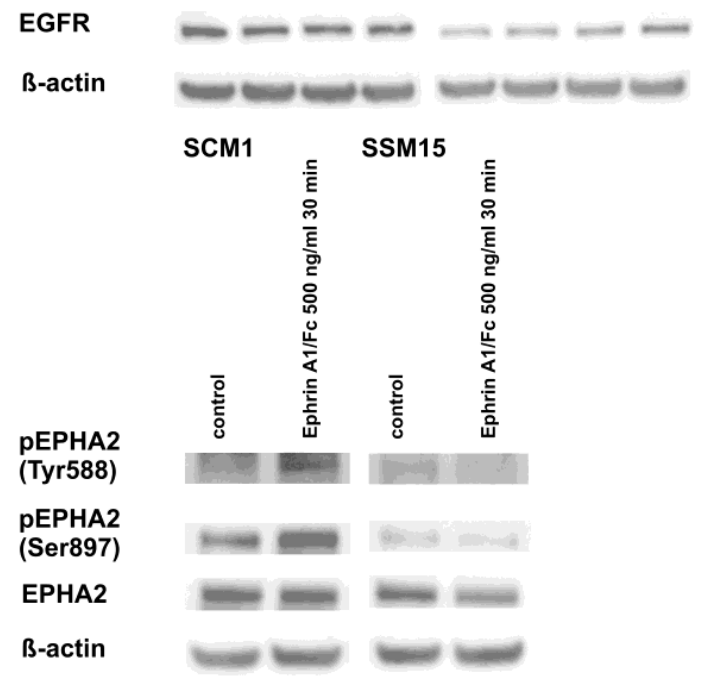

Figure 5. SIRT2 downregulation impairs the response of melanoma cells to EGFR and EPHA2 activators. The generated melanoma clones were treated with selected concentrations of EGF (EGFR activator) and ephrin A1 (EPHA2 activator) for $10 \mathrm{~min}$ and/or $30 \mathrm{~min}$, respectively. Then, protein lysates were prepared and analyzed by Western blotting. (a) Experiments performed using WM853 SCW3 and SSW30 clones. (b) Experiments performed using MDA-MB-435S SCM1 and SSM15 clones. 
a

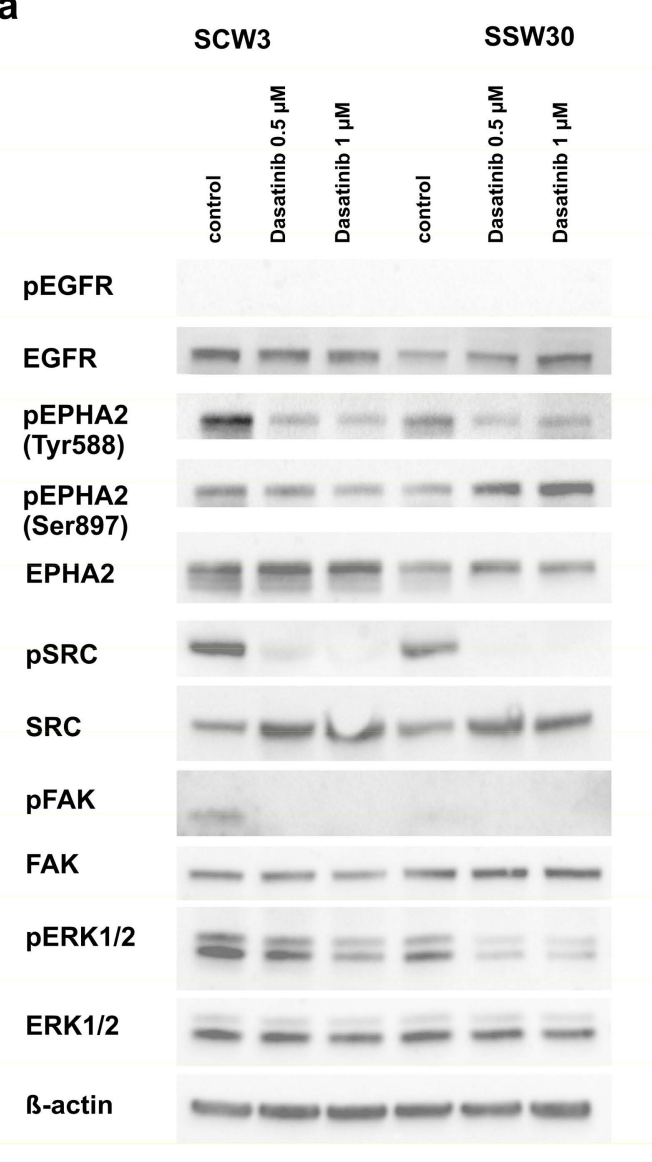

b

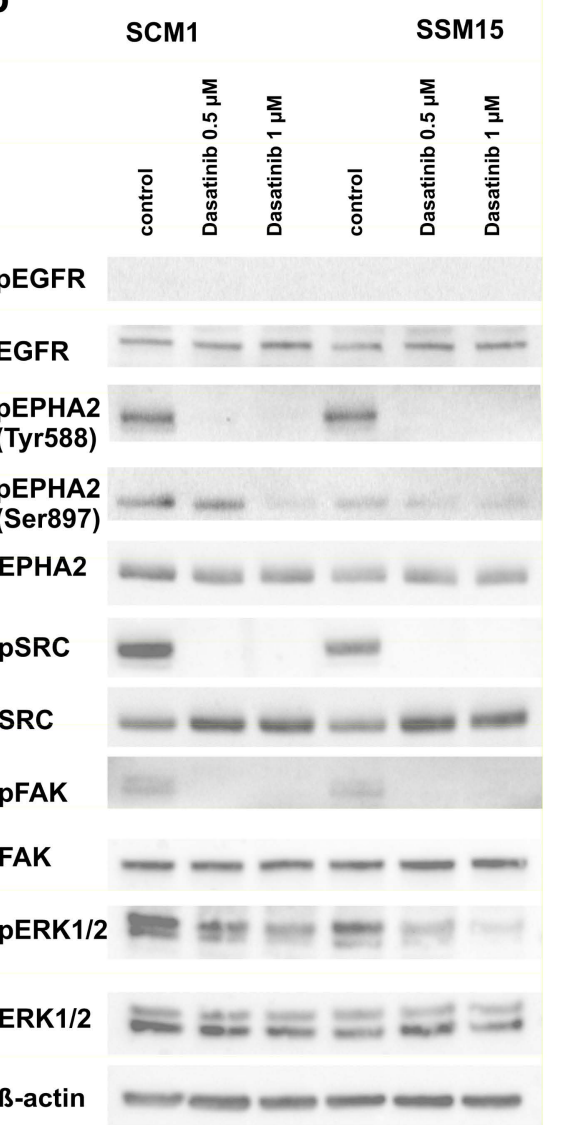

Figure 6. SIRT2 downregulation impairs the expression and phosphorylation of tyrosine kinase receptor-associated pathways. The generated melanoma clones were treated with selected concentrations of dasatinib for $1 \mathrm{~h}$. Then, protein lysates were prepared and analyzed by Western blotting. (b) Experiments performed using WM853 SCW3 and SSW30 clones. (a) Experiments performed using MDA-MB-435S SCM1 and SSM15 clones.

\section{Discussion}

Failures in the treatment of advanced melanoma require new approaches and a search for new therapeutic targets that may increase the effectiveness of therapy, similar to the discovery of the V600E BRAF mutant [25]. NAD(+)-dependent, multifunctional lysine deacylases sirtuins are among such potential molecular targets [36]. Our previous studies using the SIRT2 inhibitor have shown that SIRT2 might be involved in intracellular processes that mediate melanoma proliferation and multidrug resistance [49], prompting us to further investigate the role of this deacetylase in the biology of melanoma cells. Thus, we created melanoma cell lines with silenced SIRT2 expression. We chose the WM853 line, representing the primary/vertical growth stage and MDA-MD-435S representing metastatic melanoma as previous studies indicated that the role of SIRT2 might change with the advancement of cancer development [52]. Transcriptome analysis demonstrated that SIRT2 has important regulatory roles in the expression of multiple genes associated with the molecular signatures of melanoma progression [71]. Among the genes that were downregulated by silencing this deacetylase are those that have been positively correlated with melanoma aggressiveness [71] (e.g., NCAPG, CDKN2C, GINS1, and DHFR are all downregulated in the SSW30 clone, Dataset S1). Among genes that were upregulated by SIRT2 silencing were those that are downregulated in aggressive melanoma cells (e.g., MGST1 is upregulated in the SSW30 and SSM15 clones, Datasets S1 and S2). Similarly, genes related to melanoma invasion were downregulated in SIRT2-deficient melanoma cell lines (e.g., HLA-DRA, IL-6, CD74, and HLA-DRB1 in the SSW30 clone, Dataset S1; PTPRZ1, FST, and NRCAM in 
the SSM15 clone, Dataset S2). Interestingly, although the two cell lines represented different stages of disease, we obtained similar levels of SIRT2 silencing. In WM853 cells, substantially more genes were differentially regulated than in metastatic MDA-MB- $435 \mathrm{~S}$ cells. This finding might indicate that in the VG phase, SIRT2 plays a more prominent regulatory function associated with the acquisition of metastatic properties and suggests that SIRT2 in tumors in this phase could represent a better therapeutic target compared with those in the metastatic phase. Among the differentially expressed genes, we found numerous genes that are molecular targets for dasatinib [65]. Consistent with this observation, both melanoma cell lines with silenced SIRT2 expression showed greater susceptibility to dasatinib than control cells as evidenced by several experimental approaches, including neutral red uptake, caspase 3/7 activity, and clonogenic assays (Figure 1, Figure 2 and Figure S3). We also showed that SIRT2 loss substantially decreased the migration of melanoma cells, and treatment with dasatinib further increased this inhibition of migration (Figure 3). In analyses of cell percentages in different cell cycle phases, we noticed that inhibition of SIRT2 expression arrested cells in S phase and that dasatinib enhanced this effect (Figure 4). Taken together, these observations are consistent with the hypothesis that SIRT2 regulates some putative elements necessary for activation of the MAPK pathway in the absence of V600E mutated BRAF-mediated activation. This hypothesis is consistent with RNA-seq results showing that SIRT2 regulates the expression of genes coding for tyrosine kinase receptors and MAPK/ERK pathway signaling molecules (Tables 1 and 2; Datasets S1 and S2). This hypothesis is also consistent with the observations that dasatinib mediates different protein phosphorylation profiles in SIRT2-deficient melanoma cells than in control cells (Figures 5 and 6). Our results are consistent with those of Wilking-Busch et al. [72], who showed that inhibition of SIRT2 expression in the melanoma A375 cell line led to a decrease in cell proliferation and the ability to form colonies, and they contradict the results of Bajpe et al. [50], who showed that inhibition of SIRT2 expression was associated with increased ERK phosphorylation and conferred resistance to cetuximab, AZD6244, and vemurafenib. Previous studies have suggested that SIRT2 may act as both a tumor promoter and suppressor [52], [73]. Our previous study [49], the work of Wilking-Busch et al. [72] and this report demonstrate that SIRT2 in melanomas acts as a tumor promoter at least in the context of the tested drugs and is a promising candidate for new anti-melanoma targeted therapies.

Dasatinib was first identified as a Src/Abl kinase inhibitor [74], and subsequent studies have shown that it also targets other kinases [65,75]. Dasatinib exhibits activity against melanomas in vitro [76], but its clinical use in melanoma monotherapy has been disappointing [77]. The use of dasatinib in combination with dacarbazine has provided slightly better results [78], but they remain far from expectations. Our study provides evidence that SIRT2 is one factor responsible for the resistance of melanoma cells to dasatinib. A possible explanation for SIRT2-mediated regulation of melanoma cell sensitivity to dasatinib is the role of this deacetylase in the regulation of genes encoding tyrosine kinase receptors and other signaling molecules that are responsible for the function of the main signaling pathway targeted by this drug $[65,75]$.

In 50\% of patients undergoing treatment with vemurafenib [26] or dabrafenib [27] (V600E BRAF inhibitors), resistance to these drugs develops after $6-8$ months, which might be due to reactivation of the MAPK pathway [30-34]. Therefore, combination therapy with BRAF inhibitor and trametinib (MEK1/2 inhibitor) has improved clinical outcomes [79], but has not solved the problem of emerging resistance [80]. Activation of survival signaling through receptor tyrosine kinases (RTKs), e.g., EGFR $[81,82]$, is also involved in the observed acquired resistance to the mentioned drugs. Our transcriptomic analysis showed that loss of SIRT2 in both P/VG and metastatic melanoma cell lines was associated with decreased expression of EGFR and EPHA2, receptors that are important for the development, proliferation and acquisition of multidrug resistance by melanoma cells $[68,81,83-90]$. Western blotting confirmed that EPHA2 and EGFR expression was reduced in cells without SIRT2 and that dasatinib treatment inhibited the phosphorylation of these receptors and the downstream signaling elements Src, ERK1/2 and FAK. 
The practical consequences of the hypothesis that SIRT2 regulates genes encoding tyrosine kinase receptors and other signaling molecules that are critical for the function of the main signaling pathway targeted by dasatinib and V600E inhibitors $[65,75]$ should be considered in light of new combination therapies for the treatment of melanoma. One combination worth exploring would be the use of specific inhibitors of SIRT2 together with dasatinib to increase the clinical potential of the latter. Another potential combination would be the SIRT2 inhibitor combined with the vemurafenib-trametinib regimen to increase the time to appearance of resistance to vemurafenib or to completely eliminate this resistance. Unfortunately, to our knowledge, there are no known SIRT2 or other SIRT inhibitors undergoing clinical evaluation for the treatment of cancer to date. The SIRT1 inhibitor EX-527 was tested in a phase II clinical study in Huntington's disease patients and was well tolerated [91]. The major problem with known SIRT inhibitors is their selectivity [92]. However, the identification of the novel, SIRT2-specific inhibitor SirReal2 with 1000-fold selectivity over SIRTs 1, 3, 4, 5, and 6 [93] is a promising development that may potentially open new avenues for future clinical applications.

\section{Materials and Methods}

\subsection{Cell Lines, Cell Culture and Reagents}

The human melanoma cell lines MDA-MB-435S (stage: metastatic) and A375 (stage: metastatic) were obtained from ATCC (Manassas, VA., USA) and maintained in Dulbecco's Modified Eagle's Medium supplemented with 10\% fetal bovine serum (PAN-Biotech GmbH, Aidenbach, Germany) at $37{ }^{\circ} \mathrm{C}$ in a humidified atmosphere containing $5 \% \mathrm{CO}_{2}$. The human melanoma cell line WM853 (stage: primary/vertical growth) was purchased from Rockland (Rockland, Limerick, PA, USA) and was maintained in Tumor Specialized Medium containing 80\% MCDB153 (Sigma-Aldrich, St. Louis, MO, USA), 20\% Leibovitz's (Sigma-Aldrich, St. Louis, MO, USA), 2\% fetal bovine serum (Pan Biotech $\mathrm{GmbH}$, Aidenbach, Germany), $1.68 \mathrm{mM}$ calcium chloride, and $1.2 \mathrm{~g}(11.2 \mathrm{mM})$ sodium bicarbonate at $37^{\circ} \mathrm{C}$ in a humidified atmosphere containing $5 \% \mathrm{CO}_{2}$. Human EGF and Ephrin-A1/Fc Chimera were purchased from Sigma-Aldrich. Thiomyristoyl was purchased from Cayman Chemical (Ann Arbor, MI, USA).

\subsection{Stable SIRT2 Knockdown Melanoma Cell Line Generation}

To establish stable SIRT2-silenced cell lines, MDA-MB-435S and WM853 cells were transfected with short hairpin RNA (shRNA) plasmids: scrambled negative control noneffective shRNA (TR30012) or SIRT2 (T301692D) (Origene Tech. Rockville, MD, USA). Transfection was performed with Metafectene PRO (Biontex, München, Germany) following the manufacturer's instructions. The cells were then cultured by replacing the medium every three days with complete medium containing $1 \mu \mathrm{g} / \mathrm{mL}$ (for MDA-MB-435S) and $0.4 \mu \mathrm{g} / \mathrm{mL}$ (for WM853) puromycin for one month during which the following stable clones were selected: WM853 SCW3, control; WM853 SSW30, downregulated SIRT2; MDA-MB-435S SCM1, control; MDA-MB-435S SSM15, downregulated SIRT2. SIRT2 expression in selected clones was determined by immunoblotting analysis.

\subsection{RNA Extraction, Reverse Transcription and Quantitative PCR}

Cells were lysed using TRI reagent (Sigma Aldrich, St. Louis, MO, USA). Briefly, $5 \mu \mathrm{g}$ of total RNA was reverse transcribed using the Maxima First Strand cDNA Synthesis Kit for RT-quantitative PCR (Thermo Fisher Scientific, Waltham, MA, USA). Real-time quantitative PCR was performed using SYBR Green I Master Mix (Basel, Switzerland). The reactions were run on a LightCycler 480 from Roche under the following conditions: $95^{\circ} \mathrm{C}$ for $5 \mathrm{~min}$ followed by 40 cycles of $95^{\circ} \mathrm{C}$ for $10 \mathrm{~s}, 60^{\circ} \mathrm{C}$ for $10 \mathrm{~s}$, and $72{ }^{\circ} \mathrm{C}$ for $20 \mathrm{~s}$. The following primers were used: SIRT2, 5'-GAAGGACAAGGGGCTACTCC-3' (forward) and 5'-GATATCAGGCTTCACCAGGC-3' (reverse); EGFR, 5' -GTGCAGGAGAGGAGAACTGC-3' (forward) and 5'-GGCACCAAAGCTGTATTTGC-3' (reverse); EPHA2, 5'-TACGAGAAGGTGG AGGATGC-3' (forward) and 5'-ACGGCTGTGAGGTAGTGTGG-3' (reverse); ITGA1, 5' -TGGGTGC 
TTATTGGTTCTCC-3' (forward) and 5'-AAATCCTCCATTTGGGTTGG-3' (reverse); SDC2, 5'-CTGCTCCAAAAGTGGAAACC-3' (forward) and 5' -CAGCAATGACAGCTGCTAGG-3' (reverse); GAK, 5'-TCACCAACCTCAAGGACACC-3' (forward) and 5'-CTTGGAGTCCAGGAACAACC-3' (reverse); DDR1， 5'-GGTCAGGAGGTGATCTCAGG-3' (forward) and 5'-TGGAGTCG TTGAGGTACACG-3' (reverse); and EPHB1, 5'-CTTTGACCCTCCAGAAGTGG-3' (forward) and $5^{\prime}$-CTCCACATTGTCGTCACAGC-3' (reverse). The mRNA levels were normalized to the RPL13A housekeeping gene as described by Vandensompele et al. [94].

\subsection{Western Blotting}

Whole cell lysates were prepared using ice-cold RIPA buffer (50 mM Tris-HCl pH 8.0, 150 mM $\mathrm{NaCl}, 0.1 \%$ Triton $\mathrm{X}-100,0.1 \%$ SDS, $0.5 \%$ sodium deoxycholate) supplemented with Halt Protease Inhibitor Cocktail (Thermo Fisher Scientific). The samples were centrifuged for $15 \mathrm{~min}$ at 10,000× $g$. The protein concentration in the supernatant was determined using the Pierce BCA Protein Assay kit (Thermo Fisher Scientific). Total protein was separated on a 12\% Bis-Tris NuPage precast gel (Thermo Fisher Scientific) and transferred to a Hybond-C membrane (GE Healthcare Life Sciences, Marlborough, MA, USA) using the iBlot dry blotting system (Thermo Fisher Scientific). The membranes were blocked with $5 \%$ milk and incubated overnight with the appropriate primary antibodies at $4{ }^{\circ} \mathrm{C}$ and subsequently with HRP-conjugated secondary antibody (ab6721, Abcam, Cambridge, UK) for $1 \mathrm{~h}$ at RT. The following primary antibodies were used: anti-SIRT2 (EPR1667) (Abcam), anti-beta Actin (Abcam), EphA2 (phospho Tyr588) (GeneTex, Irvine, CA, USA), Phospho-EphA2 (Ser897) (D9A1) (Cell Signaling, Danvers, MA, USA), EphA2 (D4A2) (Cell Signaling), EGF Receptor (Cell Signaling), Phospho-EGF Receptor (Tyr1068) (D7A5) (Cell Signaling), Src (Cell Signaling), Phospho-Src Family (Tyr416) (Cell Signaling), ERK 1/2 Antibody (C-9) (Santa Cruz, Dallas, TX, USA), and Phospho-ERK (E-4) (Santa Cruz). Specific bands were visualized using SuperSignal West Pico Chemiluminescent Substrate (Thermo Fisher Scientific) and the G-Box chemiluminescence imaging station (Syngene, Cambridge, UK). The signal strength in cognate bands corresponding to the assayed proteins was quantified with G-Box station software. Original scans are available in Supplementary Materials (Original scans of Figures 1, 5 and 6).

\subsection{Preparation of Libraries, Sequencing and RNA-seq Data Analysis}

Global analysis of gene expression in WM853 SCW3, WM853 SSW30, MDA-MBA-435S SCM1 and MDA-MB-435S SSM15 clones was analyzed by high-resolution RNA sequencing (RNA-seq). The procedure applied for the preparation of libraries and sequencing has been described in detail in our previous study [95]. A Venn diagram was used to compare the identified DEGs from the different expression analysis tools and to designate the shared DEGs. An FC cut off value of 1.5-fold was used for the detection of DEGs. RNA-seq results are available under SRA accession: PRJNA530710: https://www.ncbi.nlm.nih.gov/sra/PRJNA530710.

\subsection{Gene Ontology Analysis}

Gene ontology was performed using PANTHER software [96]. The following parameters were used in the analysis: displaying only results for FDR $p<0.05$; analysis type: PANTHER overrepresentation test; reference list: Homo sapiens (all genes in database); test type: Fisher's exact; and correction: false discovery rate.

\subsection{Cell Cycle Analysis}

Cells were seeded in 6-well plates. After $24 \mathrm{~h}$, cells were treated with dasatinib for an additional $24 \mathrm{~h}$. Then, the cells were harvested, collected, washed twice in ice-cold PBS and fixed in ice-cold 70\% ethanol overnight at $4{ }^{\circ} \mathrm{C}$. The cells were then washed twice in ice-cold PBS, and DNA was stained with a solution containing $10 \mu \mathrm{g} / \mathrm{mL}$ propidium iodide, $0.1 \%$ Triton X-100 and $100 \mu \mathrm{g} / \mathrm{mL}$ RNase A at RT for $30 \mathrm{~min}$. The cell samples were measured with a LSRFortessa (Becton-Dickinson, Franklin Lakes, USA) 
flow cytometer. Data acquisition and analysis were performed using FlowJo 7.6.5 software (Treestar Data Analysis Software., Ashland, OR., USA).

\subsection{In Vitro Scratch Assay}

The migratory potential of the cell lines was assayed using the in vitro scratch assay [97]. Cells were grown on 12-well plates until monolayer formation; then, a scratch was created using a 200- $\mu \mathrm{L}$ pipette tip. The cells were then treated with increasing concentrations of dasatinib. After $24 \mathrm{~h}$ and $48 \mathrm{~h}$ of incubation, the plates were placed under an Eclipse TE2000 inverted microscope (Nikon, Tokyo, Japan), and images of the scratch were acquired. The data were analyzed using ImageJ (http://imagej.nih.gov/ij/).

\subsection{Detection of Early Cellular Membrane Damage}

Cells were seeded in 96-well plates at a density of $1 \times 10^{4}$ per well. After $24 \mathrm{~h}$, the cells were treated with dasatinib. Staining solution $(0.35 \mu \mathrm{M}$ YO-PRO-1 in an appropriate cell culture medium) prewarmed to $37^{\circ} \mathrm{C}$ was added $24 \mathrm{~h}$ after the treatment, and the cells were incubated for $30 \mathrm{~min}$. The medium was then removed, and the cells were washed twice with PBS. Cells were fixed with fixation solution (3.7\% formaldehyde in PBS) and incubated with nuclear staining solution $(10 \mu \mathrm{g} / \mathrm{mL}$ Hoechst 33,342 in PBS) for 20 min. After 3 washes with PBS, the plates were scanned in the ArrayScan VTi HCS Reader (Thermo Fisher Scientific), and the fluorescence of YO-PRO-1 (a marker of cell membrane damage) was analyzed.

\subsection{Cell Viability Measurements}

For the determination of cell viability, the neutral red cytotoxicity assay was used [98], as described in our previous study [99].

\subsection{Caspase 3/7 Activity Measurements}

For the determination of apoptosis, caspase 3 and 7 activities were measured using the Caspase-Glo ${ }^{\circledR}$ 3/7 Assay System from Promega (Madison, WI, USA) according to the manufacturer's protocol. The luminescence measurements were performed on an Infinite 200 PRO (Tecan, Männedorf, Switzerland) plate reader.

\subsection{Colony Formation Assay}

Cells were seeded in a 6-well plate at a density 1000 cells per well. After incubation for $24 \mathrm{~h}$, the cells were treated with dasatinib for 14 days. Colonies were fixed with $100 \%$ methanol and stained with $0.5 \%$ crystal violet solution [100]. Plates were scanned using G-Box (Synoptics, Cambridge, UK), and images were analyzed using ImageJ as described previously by Guzman et al. [101].

\subsection{Statistics}

Testing for statistical significance was performed by ANOVA followed by the Tukey's post hoc test. When two means were compared, student's $t$-test was used. When $p<0.05$, the observed difference was considered statistically significant.

\section{Conclusions}

In conclusion, our results show for the first time that SIRT2 is an important regulator of the basic functions and genes of melanoma cells, including those involved in cell motility, proliferation and drug resistance. We provide new tools in the form of cell lines lacking SIRT2 expression to study the role of this sirtuin in melanoma cells. Low SIRT2 levels alter the expression of tyrosine kinase receptors and induce melanoma cell susceptibility to the multikinase inhibitor dasatinib. Thus, we explained one of the possible resistance mechanisms to this drug. As a consequence of this finding, to improve 
therapeutic potential of present regiments against melanoma, inhibition of sirtuin 2 activity should be considered.

Supplementary Materials: The following are available online at http://www.mdpi.com/2072-6694/11/5/673/s1, Figure S1: Phenotypes of the SIRT2-deficient melanoma cell lines, Figure S2: Venn diagrams to compare the identified DEGs from the different expression analysis tools and designate the shared DEGs, Figure S3: Individual cytotoxic effects of dasatinib on melanoma cell lines, Figure S4: Computer-generated area lacking values to illustrate the in vitro scratch assay from Figure 3, Table S1: Gene ontology (biological process) term results from the PANTHER overrepresentation test for significantly differentially expressed (DE) genes regulated in both melanoma cells analyzed, Table S2: Expression of selected genes in A375 melanoma cells after treatment with the SIRT2 inhibitor thiomyristoyl, DataSet S1: A complete list of genes that changed expression in WM853 cell line after SIRT2 downregulation determined using RNA-seq, DataSet S2: A complete list of genes that changed expression in MDA-MB-435S cell line after SIRT2 downregulation determined using RNA-seq, DataSet S3: A complete list of gene ontology (biological process) term results from the PANTHER overrepresentation test for significantly differentially expressed (DE) genes regulated in WM853 SCW3/WM853 SSW30 and MDA-MB-435S SCM1/MDA-MB-435S SSM15 cells, Original scans of Figures 1, 5 and 6.

Author Contributions: Conceptualization, M.R.; methodology, M.R. and I.K.; software, M.S.-K. and D.S.; investigation, I.K., A.S., K.K., M.S.-K., A.W.-D. and M.R.; data curation, I.K., M.S.-K., D.S. and M.R.; writing —original draft preparation, J.D. and M.R.; writing — review and editing, I.K. and Ł.P.; visualization, M.R.; supervision, M.R.; project administration, M.R.; funding acquisition, M.R.

Funding: This work was supported by National Science Centre Project no. 2015/17/B/NZ5/00142. D.S. and M.S.-K. were supported by the Polish Ministry of Science and Higher Education grant DIR/WK/2017/01.

Acknowledgments: We would like to thank Marcin Słomka for technical support.

Conflicts of Interest: The authors declare no conflicts of interest.

\section{References}

1. Siegel, R.L.; Miller, K.D.; Jemal, A. Cancer statistics, 2016. CA Cancer J. Clin. 2016, 66, 7-30. [CrossRef]

2. Serrone, L.; Zeuli, M.; Sega, F.M.; Cognetti, F. Dacarbazine-based chemotherapy for metastatic melanoma: Thirty-year experience overview. J. Exp. Clin. Cancer Res. 2000, 19, 21-34. [PubMed]

3. Jilaveanu, L.B.; Aziz, S.A.; Kluger, H.M. Chemotherapy and biologic therapies for melanoma: Do they work? Clin. Dermatol. 2009, 27, 614-625. [CrossRef]

4. Atkins, M.B.; Lotze, M.T.; Dutcher, J.P.; Fisher, R.I.; Weiss, G.; Margolin, K.; Abrams, J.; Sznol, M.; Parkinson, D.; Hawkins, M.; et al. High-dose recombinant interleukin 2 therapy for patients with metastatic melanoma: Analysis of 270 patients treated between 1985 and 1993. J. Clin. Oncol. 1999, 17, 2105-2116. [CrossRef]

5. Robinson, W.A.; Mughal, T.I.; Thomas, M.R.; Johnson, M.; Spiegel, R.J. Treatment of metastatic malignant melanoma with recombinant interferon alpha 2. Immunobiology 1986, 172, 275-282. [CrossRef]

6. Banzi, M.; De Blasio, S.; Lallas, A.; Longo, C.; Moscarella, E.; Alfano, R.; Argenziano, G. Dabrafenib: A new opportunity for the treatment of BRAF v600-positive melanoma. Oncol. Targets Ther. 2016, 9, 2725-2733. [PubMed]

7. Legha, S.S.; Ring, S.; Papadopoulos, N.; Plager, C.; Chawla, S.; Benjamin, R. A prospective evaluation of a triple-drug regimen containing cisplatin, vinblastine, and dacarbazine (CVD) for metastatic melanoma. Cancer 1989, 64, 2024-2029. [CrossRef]

8. Del Prete, S.A.; Maurer, L.H.; O’Donnell, J.; Forcier, R.J.; LeMarbre, P. Combination chemotherapy with cisplatin, carmustine, dacarbazine, and tamoxifen in metastatic melanoma. Cancer Treat. Rep. 1984, 68, 1403-1405. [PubMed]

9. Fierro, M.T.; Bertero, M.; Novelli, M.; Appino, A.; Doveil, G.C.; Colonna, S.; Bernengo, M.G. Therapy for metastatic melanoma: Effective combination of dacarbazine, carmustine, cisplatin and tamoxifen. Melanoma Res. 1993, 3, 127-131. [PubMed]

10. Chen, K.G.; Leapman, R.D.; Zhang, G.; Lai, B.; Valencia, J.C.; Cardarelli, C.O.; Vieira, W.D.; Hearing, V.J.; Gottesman, M.M. Influence of melanosome dynamics on melanoma drug sensitivity. J. Natl. Cancer Inst. 2009, 101, 1259-1271. [CrossRef]

11. Chen, K.G.; Valencia, J.C.; Gillet, J.P.; Hearing, V.J.; Gottesman, M.M. Involvement of ABC transporters in melanogenesis and the development of multidrug resistance of melanoma. Pigment. Cell Melanoma Res. 2009, 22, 740-749. [CrossRef] [PubMed] 
12. Jansen, B.; Wacheck, V.; Heere-Ress, E.; Schlagbauer-Wadl, H.; Hoeller, C.; Lucas, T.; Hoermann, M.; Hollenstein, U.; Wolff, K.; Pehamberger, H. Chemosensitisation of malignant melanoma by BCL2 antisense therapy. Lancet 2000, 356, 1728-1733. [CrossRef]

13. Wolter, K.G.; Verhaegen, M.; Fernandez, Y.; Nikolovska-Coleska, Z.; Riblett, M.; de la Vega, C.M.; Wang, S.; Soengas, M.S. Therapeutic window for melanoma treatment provided by selective effects of the proteasome on BCL-2 proteins. Cell Death Differ. 2007, 14, 1605-1616. [CrossRef] [PubMed]

14. Tang, L.; Tron, V.A.; Reed, J.C.; Mah, K.J.; Krajewska, M.; Li, G.; Zhou, X.; Ho, V.C.; Trotter, M.J. Expression of apoptosis regulators in cutaneous malignant melanoma. Clin. Cancer Res. 1998, 4, 1865-1871.

15. Nikolaou, V.A.; Stratigos, A.J.; Flaherty, K.T.; Tsao, H. Melanoma: New insights and new therapies. J. Investig. Dermatol. 2012, 132, 854-863. [CrossRef] [PubMed]

16. Chartrain, M.; Riond, J.; Stennevin, A.; Vandenberghe, I.; Gomes, B.; Lamant, L.; Meyer, N.; Gairin, J.E.; Guilbaud, N.; Annereau, J.P. Melanoma chemotherapy leads to the selection of ABCB5-expressing cells. PLoS ONE 2012, 7, e36762. [CrossRef] [PubMed]

17. Levy, C.; Khaled, M.; Fisher, D.E. Mitf: Master regulator of melanocyte development and melanoma oncogene. Trends Mol. Med. 2006, 12, 406-414. [CrossRef]

18. Hirata, E.; Girotti, M.R.; Viros, A.; Hooper, S.; Spencer-Dene, B.; Matsuda, M.; Larkin, J.; Marais, R.; Sahai, E. Intravital imaging reveals how BRAF inhibition generates drug-tolerant microenvironments with high integrin $\beta 1 / F A K$ signaling. Cancer Cell 2015, 27, 574-588. [CrossRef]

19. Kaur, A.; Webster, M.R.; Marchbank, K.; Behera, R.; Ndoye, A.; Kugel, C.H., 3rd; Dang, V.M.; Appleton, J.; O'Connell, M.P.; Cheng, P.; et al. sFRP2 in the aged microenvironment drives melanoma metastasis and therapy resistance. Nature 2016, 532, 250-254. [CrossRef] [PubMed]

20. Ruffell, B.; Coussens, L.M. Macrophages and therapeutic resistance in cancer. Cancer Cell 2015, $27,462-472$. [CrossRef] [PubMed]

21. Winder, M.; Viros, A. Mechanisms of drug resistance in melanoma. Handb. Exp. Pharmacol. 2018, 249, 91-108.

22. Davies, H.; Bignell, G.R.; Cox, C.; Stephens, P.; Edkins, S.; Clegg, S.; Teague, J.; Woffendin, H.; Garnett, M.J.; Bottomley, W.; et al. Mutations of the BRAF gene in human cancer. Nature 2002, 417, 949-954. [CrossRef]

23. Wan, P.T.; Garnett, M.J.; Roe, S.M.; Lee, S.; Niculescu-Duvaz, D.; Good, V.M.; Jones, C.M.; Marshall, C.J.; Springer, C.J.; Barford, D.; et al. Mechanism of activation of the RAF-ERK signaling pathway by oncogenic mutations of B-RAF. Cell 2004, 116, 855-867. [CrossRef]

24. Roberts, P.J.; Der, C.J. Targeting the RAF-MEK-ERK mitogen-activated protein kinase cascade for the treatment of cancer. Oncogene 2007, 26, 3291-3310. [CrossRef]

25. Flaherty, K.T.; Puzanov, I.; Kim, K.B.; Ribas, A.; McArthur, G.A.; Sosman, J.A.; O’Dwyer, P.J.; Lee, R.J.; Grippo, J.F.; Nolop, K.; et al. Inhibition of mutated, activated BRAF in metastatic melanoma. N. Engl. J. Med. 2010, 363, 809-819. [CrossRef]

26. Chapman, P.B.; Hauschild, A.; Robert, C.; Haanen, J.B.; Ascierto, P.; Larkin, J.; Dummer, R.; Garbe, C.; Testori, A.; Maio, M.; et al. Improved survival with vemurafenib in melanoma with BRAF v600e mutation. N Engl. J. Med. 2011, 364, 2507-2516. [CrossRef]

27. Hauschild, A.; Grob, J.J.; Demidov, L.V.; Jouary, T.; Gutzmer, R.; Millward, M.; Rutkowski, P.; Blank, C.U.; Miller, W.H., Jr.; Kaempgen, E.; et al. Dabrafenib in BRAF-mutated metastatic melanoma: A multicentre, open-label, phase 3 randomised controlled trial. Lancet 2012, 380, 358-365. [CrossRef]

28. Ascierto, P.A.; Minor, D.; Ribas, A.; Lebbe, C.; O’Hagan, A.; Arya, N.; Guckert, M.; Schadendorf, D.; Kefford, R.F.; Grob, J.J.; et al. Phase II trial (BREAK-2) of the BRAF inhibitor dabrafenib (GSK2118436) in patients with metastatic melanoma. J. Clin. Oncol 2013, 31, 3205-3211. [CrossRef]

29. Medina, T.M.; Lewis, K.D. The evolution of combined molecular targeted therapies to advance the therapeutic efficacy in melanoma: A highlight of vemurafenib and cobimetinib. Oncol. Targets Ther. 2016, 9, 3739-3752.

30. Nazarian, R.; Shi, H.; Wang, Q.; Kong, X.; Koya, R.C.; Lee, H.; Chen, Z.; Lee, M.K.; Attar, N.; Sazegar, H.; et al. Melanomas acquire resistance to B-RAF(v600e) inhibition by RTK or N-RAS upregulation. Nature 2010, 468, 973-977. [CrossRef]

31. Lito, P.; Rosen, N.; Solit, D.B. Tumor adaptation and resistance to RAF inhibitors. Nat. Med. 2013, 19, 1401-1409. [CrossRef]

32. Maertens, O.; Johnson, B.; Hollstein, P.; Frederick, D.T.; Cooper, Z.A.; Messiaen, L.; Bronson, R.T.; McMahon, M.; Granter, S.; Flaherty, K.; et al. Elucidating distinct roles for nf1 in melanomagenesis. Cancer Discov. 2013, 3, 338-349. [CrossRef] 
33. Poulikakos, P.I.; Persaud, Y.; Janakiraman, M.; Kong, X.; Ng, C.; Moriceau, G.; Shi, H.; Atefi, M.; Titz, B.; Gabay, M.T.; et al. RAF inhibitor resistance is mediated by dimerization of aberrantly spliced BRAF(v600e). Nature 2011, 480, 387-390. [CrossRef] [PubMed]

34. Johannessen, C.M.; Boehm, J.S.; Kim, S.Y.; Thomas, S.R.; Wardwell, L.; Johnson, L.A.; Emery, C.M.; Stransky, N.; Cogdill, A.P.; Barretina, J.; et al. COT drives resistance to RAF inhibition through MAP kinase pathway reactivation. Nature 2010, 468, 968-972. [CrossRef] [PubMed]

35. Wilking, M.J.; Singh, C.K.; Nihal, M.; Ndiaye, M.A.; Ahmad, N. Sirtuin deacetylases: A new target for melanoma management. Cell Cycle 2014, 13, 2821-2826. [CrossRef]

36. Garcia-Peterson, L.M.; Wilking-Busch, M.J.; Ndiaye, M.A.; Philippe, C.G.A.; Setaluri, V.; Ahmad, N. Sirtuins in skin and skin cancers. Skin Pharmacol. Physiol. 2017, 30, 216-224. [CrossRef] [PubMed]

37. Brachmann, C.B.; Sherman, J.M.; Devine, S.E.; Cameron, E.E.; Pillus, L.; Boeke, J.D. The SIR2 gene family, conserved from bacteria to humans, functions in silencing, cell cycle progression, and chromosome stability. Genes Dev. 1995, 9, 2888-2902. [CrossRef]

38. Tanny, J.C.; Dowd, G.J.; Huang, J.; Hilz, H.; Moazed, D. An enzymatic activity in the yeast SIR2 protein that is essential for gene silencing. Cell 1999, 99, 735-745. [CrossRef]

39. Frye, R.A. Phylogenetic classification of prokaryotic and eukaryotic SIR2-like proteins. Biochem. Biophys. Res. Commun. 2000, 273, 793-798. [CrossRef]

40. Nakagawa, T.; Guarente, L. Sirtuins at a glance. J. Cell Sci. 2011, 124, 833-838. [CrossRef]

41. Huang, J.Y.; Hirschey, M.D.; Shimazu, T.; Ho, L.; Verdin, E. Mitochondrial sirtuins. Biochim. Biophys. Acta 2010, 1804, 1645-1651. [CrossRef]

42. Haigis, M.C.; Sinclair, D.A. Mammalian sirtuins: Biological insights and disease relevance. Annu. Rev. Pathol. 2010, 5, 253-295. [CrossRef] [PubMed]

43. Mendes, K.L.; Lelis, D.F.; Santos, S.H.S. Nuclear sirtuins and inflammatory signaling pathways. Cytokine Growth Factor Rev. 2017, 38, 98-105. [CrossRef]

44. Tanno, M.; Sakamoto, J.; Miura, T.; Shimamoto, K.; Horio, Y. Nucleocytoplasmic shuttling of the $\mathrm{NAD}^{+}$-dependent histone deacetylase SIRT1. J. Biol. Chem. 2007, 282, 6823-6832. [CrossRef]

45. Li, W.; Zhang, B.; Tang, J.; Cao, Q.; Wu, Y.; Wu, C.; Guo, J.; Ling, E.A.; Liang, F. Sirtuin 2, a mammalian homolog of yeast silent information regulator-2 longevity regulator, is an oligodendroglial protein that decelerates cell differentiation through deacetylating alpha-tubulin. J. Neurosci. 2007, 27, 2606-2616. [CrossRef]

46. Wang, C.; Wang, M.W.; Tashiro, S.; Onodera, S.; Ikejima, T. Roles of SIRT1 and phosphoinositide 3-Oh kinase/protein kinase C pathways in evodiamine-induced human melanoma A375-S2 cell death. J. Pharmacol. Sci. 2005, 97, 494-500. [CrossRef]

47. Kunimoto, R.; Jimbow, K.; Tanimura, A.; Sato, M.; Horimoto, K.; Hayashi, T.; Hisahara, S.; Sugino, T.; Hirobe, T.; Yamashita, T.; et al. SIRT1 regulates lamellipodium extension and migration of melanoma cells. J. Investig. Dermatol. 2017, 134, 1693-1700. [CrossRef] [PubMed]

48. Ohanna, M.; Bonet, C.; Bille, K.; Allegra, M.; Davidson, I.; Bahadoran, P.; Lacour, J.P.; Ballotti, R.; Bertolotto, C. SIRT1 promotes proliferation and inhibits the senescence-like phenotype in human melanoma cells. Oncotarget 2014, 5, 2085-2095. [CrossRef] [PubMed]

49. Karwaciak, I.; Gorzkiewicz, M.; Ryba, K.; Dastych, J.; Pulaski, L.; Ratajewski, M. AC-93253 triggers the downregulation of melanoma progression markers and the inhibition of melanoma cell proliferation. Chem. Biol. Interact. 2015, 236, 9-18. [CrossRef]

50. Bajpe, P.K.; Prahallad, A.; Horlings, H.; Nagtegaal, I.; Beijersbergen, R.; Bernards, R. A chromatin modifier genetic screen identifies SIRT2 as a modulator of response to targeted therapies through the regulation of MEK kinase activity. Oncogene 2015, 34, 531-536. [CrossRef]

51. Lai, Y.H.; Lin, S.Y.; Wu, Y.S.; Chen, H.W.; Chen, J.J.W. Ac-93253 iodide, a novel SRC inhibitor, suppresses NSCLC progression by modulating multiple SRC-related signaling pathways. J. Hematol. Oncol. 2017, 10, 172. [CrossRef]

52. McGlynn, L.M.; Zino, S.; MacDonald, A.I.; Curle, J.; Reilly, J.E.; Mohammed, Z.M.; McMillan, D.C.; Mallon, E.; Payne, A.P.; Edwards, J.; et al. SIRT2: Tumour suppressor or tumour promoter in operable breast cancer? Eur. J. Cancer 2014, 50, 290-301. [CrossRef]

53. Anders, S.; Huber, W. Differential expression analysis for sequence count data. Genome Biol. 2010, 11, R106. [CrossRef] [PubMed] 
54. Love, M.I.; Huber, W.; Anders, S. Moderated estimation of fold change and dispersion for RNA-seq data with DEseq2. Genome Biol. 2014, 15, 550. [CrossRef]

55. Robinson, M.D.; McCarthy, D.J.; Smyth, G.K. Edger: A bioconductor package for differential expression analysis of digital gene expression data. Bioinformatics 2010, 26, 139-140. [CrossRef] [PubMed]

56. Huang, R.; Rofstad, E.K. Integrins as therapeutic targets in the organ-specific metastasis of human malignant melanoma. J. Exp. Clin. Cancer Res. 2018, 37, 92. [CrossRef] [PubMed]

57. Ciolczyk-Wierzbicka, D.; Laidler, P. The inhibition of invasion of human melanoma cells through N-cadherin knock-down. Med. Oncol. 2018, 35, 42. [CrossRef]

58. Yamada, M.; Yanaba, K.; Hasegawa, M.; Matsushita, Y.; Horikawa, M.; Komura, K.; Matsushita, T.; Kawasuji, A.; Fujita, T.; Takehara, K.; et al. Regulation of local and metastatic host-mediated anti-tumour mechanisms by 1-selectin and intercellular adhesion molecule-1. Clin. Exp. Immunol. 2006, 143, $216-227$. [CrossRef]

59. Wang, C.; Tseng, T.; Jhang, Y.; Tseng, J.; Hsieh, C.; Wu, W.G.; Lee, S. Loss of cell invasiveness through PKC-mediated syndecan-1 downregulation in melanoma cells under anchorage independency. Exp. Dermatol. 2014, 23, 843-849. [CrossRef]

60. Sheppard, K.E.; McArthur, G.A. The cell-cycle regulator CDK4: An emerging therapeutic target in melanoma. Clin. Cancer Res. 2013, 19, 5320-5328. [CrossRef]

61. Iida, M.; Omata, Y.; Nakano, C.; Yajima, I.; Tsuzuki, T.; Ishikawa, K.; Hori, M.; Kato, M. Decreased expression levels of cell cycle regulators and matrix metalloproteinases in melanoma from RET-transgenic mice by single irradiation of non-equilibrium atmospheric pressure plasmas. Int. J. Clin. Exp. Pathol. 2015, 8, 9326-9331. [PubMed]

62. Abreu Velez, A.M.; Howard, M.S. Tumor-suppressor Genes, Cell Cycle Regulatory Checkpoints, and the Skin. N. Am. J. Med. Sci. 2015, 7, 176-188. [CrossRef] [PubMed]

63. Jing, H.; Hu, J.; He, B.; Negron Abril, Y.L.; Stupinski, J.; Weiser, K.; Carbonaro, M.; Chiang, Y.L.; Southard, T.; Giannakakou, P.; et al. A SIRT2-selective inhibitor promotes c-MYC oncoprotein degradation and exhibits broad anticancer activity. Cancer Cell 2016, 29, 297-310. [CrossRef]

64. Spiegelman, N.A.; Price, I.R.; Jing, H.; Wang, M.; Yang, M.; Cao, J.; Hong, J.Y.; Zhang, X.; Aramsangtienchai, P.; Sadhukhan, S.; et al. Direct comparison of SIRT2 inhibitors: Potency, specificity, activity-dependent inhibition, and on-target anticancer activities. ChemMedChem 2018, 13, 1890-1894. [CrossRef]

65. Rix, U.; Hantschel, O.; Durnberger, G.; Remsing Rix, L.L.; Planyavsky, M.; Fernbach, N.V.; Kaupe, I.; Bennett, K.L.; Valent, P.; Colinge, J.; et al. Chemical proteomic profiles of the BCR-ABL inhibitors imatinib, nilotinib, and dasatinib reveal novel kinase and nonkinase targets. Blood 2007, 110, 4055-4063. [CrossRef]

66. Li, J.; Rix, U.; Fang, B.; Bai, Y.; Edwards, A.; Colinge, J.; Bennett, K.L.; Gao, J.; Song, L.; Eschrich, S.; et al. A chemical and phosphoproteomic characterization of dasatinib action in lung cancer. Nat. Chem. Biol. 2010, 6, 291-299. [CrossRef]

67. Ivanov, V.N.; Hei, T.K. Combined treatment with EGFR inhibitors and arsenite upregulated apoptosis in human EGFR-positive melanomas: A role of suppression of the PI3K-AKT pathway. Oncogene 2005, 24, 616-626. [CrossRef]

68. Miao, B.; Ji, Z.; Tan, L.; Taylor, M.; Zhang, J.; Choi, H.G.; Frederick, D.T.; Kumar, R.; Wargo, J.A.; Flaherty, K.T.; et al. $\mathrm{E} \alpha 2$ is a mediator of vemurafenib resistance and a novel therapeutic target in melanoma. Cancer Discov. 2015, 5, 274-287. [CrossRef]

69. Fu, Y.M.; Yu, Z.X.; Pelayo, B.A.; Ferrans, V.J.; Meadows, G.G. Focal adhesion kinase-dependent apoptosis of melanoma induced by tyrosine and phenylalanine deficiency. Cancer Res. 1999, 59, 758-765.

70. Liu, J.D.; Chen, S.H.; Lin, C.L.; Tsai, S.H.; Liang, Y.C. Inhibition of melanoma growth and metastasis by combination with (-)-epigallocatechin-3-gallate and dacarbazine in mice. J. Cell. Biochem. 2001, 83, 631-642. [CrossRef]

71. Ryu, B.; Kim, D.S.; Deluca, A.M.; Alani, R.M. Comprehensive expression profiling of tumor cell lines identifies molecular signatures of melanoma progression. PLOS ONE 2007, 2, e594. [CrossRef] [PubMed]

72. Wilking-Busch, M.J.; Ndiaye, M.A.; Liu, X.; Ahmad, N. RNA interference-mediated knockdown of SIRT1 and/or SIRT2 in melanoma: Identification of downstream targets by large-scale proteomics analysis. J. Proteom. 2018, 170, 99-109. [CrossRef] [PubMed]

73. Li, Z.; Xie, Q.R.; Chen, Z.; Lu, S.; Xia, W. Regulation of SIRT2 levels for human non-small cell lung cancer therapy. Lung Cancer 2013, 82, 9-15. [CrossRef] 
74. Lombardo, L.J.; Lee, F.Y.; Chen, P.; Norris, D.; Barrish, J.C.; Behnia, K.; Castaneda, S.; Cornelius, L.A.; Das, J.; Doweyko, A.M.; et al. Discovery of n-(2-chloro-6-methyl- phenyl)-2-(6-(4-(2-hydroxyethyl)piperazin-1-yl)-2-methylpyrimidin-4- ylamino)thiazole-5-carboxamide (BMS-354825), a dual SRC/ABL kinase inhibitor with potent antitumor activity in preclinical assays. J. Med. Chem. 2004, 47, 6658-6661. [CrossRef]

75. Wang, X.D.; Reeves, K.; Luo, F.R.; Xu, L.A.; Lee, F.; Clark, E.; Huang, F. Identification of candidate predictive and surrogate molecular markers for dasatinib in prostate cancer: Rationale for patient selection and efficacy monitoring. Genome Biol. 2007, 8, R255. [CrossRef]

76. Eustace, A.J.; Crown, J.; Clynes, M.; O'Donovan, N. Preclinical evaluation of dasatinib, a potent SRC kinase inhibitor, in melanoma cell lines. J. Transl. Med. 2008, 6, 53. [CrossRef]

77. Kluger, H.M.; Dudek, A.Z.; McCann, C.; Ritacco, J.; Southard, N.; Jilaveanu, L.B.; Molinaro, A.; Sznol, M. A phase 2 trial of dasatinib in advanced melanoma. Cancer 2011, 117, 2202-2208. [CrossRef]

78. Algazi, A.P.; Weber, J.S.; Andrews, S.C.; Urbas, P.; Munster, P.N.; DeConti, R.C.; Hwang, J.; Sondak, V.K.; Messina, J.L.; McCalmont, T.; et al. Phase I clinical trial of the SRC inhibitor dasatinib with dacarbazine in metastatic melanoma. Br. J. Cancer 2012, 106, 85-91. [CrossRef]

79. Flaherty, K.T.; Infante, J.R.; Daud, A.; Gonzalez, R.; Kefford, R.F.; Sosman, J.; Hamid, O.; Schuchter, L.; Cebon, J.; Ibrahim, N.; et al. Combined BRAF and MEK inhibition in melanoma with BRAF v600 mutations. N. Engl. J. Med. 2012, 367, 1694-1703. [CrossRef]

80. Long, G.V.; Fung, C.; Menzies, A.M.; Pupo, G.M.; Carlino, M.S.; Hyman, J.; Shahheydari, H.; Tembe, V.; Thompson, J.F.; Saw, R.P.; et al. Increased MAPK reactivation in early resistance to dabrafenib/trametinib combination therapy of BRAF-mutant metastatic melanoma. Nat. Commun. 2014, 5, 5694. [CrossRef]

81. Corcoran, R.B.; Ebi, H.; Turke, A.B.; Coffee, E.M.; Nishino, M.; Cogdill, A.P.; Brown, R.D.; Della Pelle, P.; Dias-Santagata, D.; Hung, K.E.; et al. EGFR-mediated Re-activation of MAPK signaling contributes to insensitivity of BRAF mutant colorectal cancers to RAF inhibition with vemurafenib. Cancer Discov. 2012, 2, 227-235. [CrossRef]

82. Girotti, M.R.; Pedersen, M.; Sanchez-Laorden, B.; Viros, A.; Turajlic, S.; Niculescu-Duvaz, D.; Zambon, A.; Sinclair, J.; Hayes, A.; Gore, M.; et al. Inhibiting EGF receptor or SRC family kinase signaling overcomes BRAF inhibitor resistance in melanoma. Cancer Discov. 2013, 3, 158-167. [CrossRef]

83. Huang, T.S.; Rauth, S.; Das Gupta, T.K. Overexpression of EGF receptor is associated with spontaneous metastases of a human melanoma cell line in nude mice. Anticancer Res. 1996, 16, 3557-3563.

84. Ma, D.; Niederkorn, J.Y. Role of epidermal growth factor receptor in the metastasis of intraocular melanomas. Invest. Ophthalmol. Vis. Sci. 1998, 39, 1067-1075.

85. Qiu, L.; Wang, Q.; Di, W.; Jiang, Q.; Schefeller, E.; Derby, S.; Wanebo, H.; Yan, B.; Wan, Y. Transient activation of EGFR/AKT cell survival pathway and expression of survivin contribute to reduced sensitivity of human melanoma cells to betulinic acid. Int. J. Oncol. 2005, 27, 823-830.

86. Straume, O.; Akslen, L.A. Importance of vascular phenotype by basic fibroblast growth factor, and influence of the angiogenic factors basic fibroblast growth factor/fibroblast growth factor receptor- 1 and ephrin-a1/epha2 on melanoma progression. Am. J. Pathol. 2002, 160, 1009-1019. [CrossRef]

87. Easty, D.J.; Hill, S.P.; Hsu, M.Y.; Fallowfield, M.E.; Florenes, V.A.; Herlyn, M.; Bennett, D.C. Up-regulation of ephrin-a1 during melanoma progression. Int J. Cancer 1999, 84, 494-501. [CrossRef]

88. Margaryan, N.V.; Strizzi, L.; Abbott, D.E.; Seftor, E.A.; Rao, M.S.; Hendrix, M.J.; Hess, A.R. Epha2 as a promoter of melanoma tumorigenicity. Cancer Biol. Ther. 2009, 8, 279-288. [CrossRef]

89. Parri, M.; Taddei, M.L.; Bianchini, F.; Calorini, L.; Chiarugi, P. Epha2 reexpression prompts invasion of melanoma cells shifting from mesenchymal to amoeboid-like motility style. Cancer Res. 2009, 69, 2072-2081. [CrossRef]

90. Udayakumar, D.; Zhang, G.; Ji, Z.; Njauw, C.N.; Mroz, P.; Tsao, H. Epha2 is a critical oncogene in melanoma. Oncogene 2011, 30, 4921-4929. [CrossRef]

91. Sussmuth, S.D.; Haider, S.; Landwehrmeyer, G.B.; Farmer, R.; Frost, C.; Tripepi, G.; Andersen, C.A.; Di Bacco, M.; Lamanna, C.; Diodato, E.; et al. An exploratory double-blind, randomized clinical trial with selisistat, a sirt1 inhibitor, in patients with huntington's disease. Br. J. Clin. Pharmacol. 2015, 79, 465-476. [CrossRef] 
92. Carafa, V.; Rotili, D.; Forgione, M.; Cuomo, F.; Serretiello, E.; Hailu, G.S.; Jarho, E.; Lahtela-Kakkonen, M.; Mai, A.; Altucci, L. Sirtuin functions and modulation: From chemistry to the clinic. Clin. Epigenet. 2016, 8, 61. [CrossRef]

93. Rumpf, T.; Schiedel, M.; Karaman, B.; Roessler, C.; North, B.J.; Lehotzky, A.; Olah, J.; Ladwein, K.I.; Schmidtkunz, K.; Gajer, M.; et al. Selective SIRT2 inhibition by ligand-induced rearrangement of the active site. Nat. Commun. 2015, 6, 6263. [CrossRef] [PubMed]

94. Vandesompele, J.; De Preter, K.; Pattyn, F.; Poppe, B.; Van Roy, N.; De Paepe, A.; Speleman, F. Accurate normalization of real-time quantitative RT-PCR data by geometric averaging of multiple internal control genes. Genome Biol. 2002, 3, RESEARCH0034. [CrossRef] [PubMed]

95. Karas', K.; Sałkowska, A.; Sobalska-Kwapis, M.; Walczak-Drzewiecka, A.; Strapagiel, D.; Dastych, J.; Bachorz, R.A. and Ratajewski, M. Digoxin, an overlooked agonist of ROR $\gamma /$ ROR $\gamma$ T. Front. Pharmacol. 2019, 9, 1460. [CrossRef]

96. Mi, H.; Huang, X.; Muruganujan, A.; Tang, H.; Mills, C.; Kang, D.; Thomas, P.D. Panther version 11: Expanded annotation data from gene ontology and reactome pathways, and data analysis tool enhancements. Nucleic Acids Res. 2017, 45, D183-D189. [CrossRef]

97. Liang, C.C.; Park, A.Y.; Guan, J.L. In vitro scratch assay: A convenient and inexpensive method for analysis of cell migration in vitro. Nat. Protoc. 2007, 2, 329-333. [CrossRef]

98. Repetto, G.; del Peso, A.; Zurita, J.L. Neutral red uptake assay for the estimation of cell viability/cytotoxicity. Nat. Protoc. 2008, 3, 1125-1131. [CrossRef]

99. Ratajewski, M.; Walczak-Drzewiecka, A.; Salkowska, A.; Dastych, J. Aflatoxins upregulate CYP3A4 mRNA expression in a process that involves the pxr transcription factor. Toxicol. Lett. 2011, 205, 146-153. [CrossRef] [PubMed]

100. Crowley, L.C.; Christensen, M.E.; Waterhouse, N.J. Measuring survival of adherent cells with the colony-forming assay. Cold Spring Harb. Protoc. 2016, 2016, 8. [CrossRef]

101. Guzman, C.; Bagga, M.; Kaur, A.; Westermarck, J.; Abankwa, D. Colonyarea: An ImageJ plugin to automatically quantify colony formation in clonogenic assays. PLoS ONE 2014, 9, e92444. [CrossRef] [PubMed]

(C) 2019 by the authors. Licensee MDPI, Basel, Switzerland. This article is an open access article distributed under the terms and conditions of the Creative Commons Attribution (CC BY) license (http://creativecommons.org/licenses/by/4.0/). 